\title{
The Effectiveness of Three Methods of Teaching Reading on Students' Achievement in Comprehension
}

\author{
Dr. (Mrs.) Felicia N. Ofuani \\ Department of Curriculum and Instructional Technology, Faculty of Education \\ University of Benin, Benin City; Felicia.ofuani@gmail.com
}

Prof. Uche B. Gbenedio

Institute of Education, University of Benin, Benin City

Doi:10.5901/jesr.2016.v6n1p17

\section{Abstract}

Reading is a fundamental skill in the learning process and personal development of an individual. This study examined the relative effectiveness of three methods of teaching reading on students' achievement in comprehension. A quasi experimental design was adopted for the study. A sample of four hundred and ninety eight (498) students was selected using multi-stage random sampling. Three research questions were raised and one hypothesis was formulated for the study. Reading Comprehension Achievement Tests (RCAT) I and II were respectively used as pre-test and post-test. Mean, standard deviation, ANCOVA and Scheffe's post hoc test were used for analysis. Results from the study showed that the individualized method is superior to both the language experience and basal method. The results suggest that teachers should be encouraged to use it in teaching reading. It was therefore recommended that attention should be paid to the teaching of reading at the secondary school level as it is the practice in primary schools.

Keywords: Reading, Methods, Comprehension, Skills, Language.

\section{Introduction}

Reading, one of the language skills, is an important skill needed in today's complex society by everyone. It is a fundamental skill in the learning process and personal development of an individual. Every child needs to develop reading skills in order to succeed in school and to discharge responsibilities as a citizen in a democratic society (Okebukola, 2004). Educators are in agreement with the fact that the reading skill is the most important skill that children learn. It is the children's primary gateway to all other knowledge they will acquire in school. Children who do not establish strong foundations of reading skills by the third grade are likely to struggle with reading throughout their lives (National Centre to Improve the Tools of Educators, 1996). Reading skill strongly predicts their future educational success, including their risk of dropping out of school as well as their career endeavours (Slavin, Karweit and Madden, 1989).

Reading involves the active participation of the reader who makes connections between existing knowledge and the construction of meaning from the materials read. Reading is an activity rather than a passive process (Arua, 2009) in which the reader is actively involved in bringing something to the reading process and activating his/her background knowledge, querying, assessing, evaluating, critiquing the content and form of the text and agreeing or disagreeing with fact, opinion and style of the text. Brozo and Hargis (2003) highlighted the importance of sustained reading in enhancing reading skills and vocabulary. The more time students spend on reading, the more growth they make. Reading and comprehension are inseparable as they are seen as two sides of a coin. Reading cannot be said to have taken place if comprehension did not take place.

In spite of the glaring importance of reading in the life of the individual, many students leave secondary school without acquiring the skills of reading. Reading is so central to educational achievement that ineffective and inefficient readers perform poorly in all school subjects. Many teachers in the secondary schools in Nigeria do not appreciate the central role of reading in the school system hence they pay little attention to the reading needs of their students. Perhaps they lack the awareness of the importance of reading in the development of the individual and its importance as a tool of emancipation. In fact, it is doubtful if they teach reading using well known methods.

Three methods; the basal, the language experience the individualized used for teaching reading in the secondary 
school have been identified with a view to testing their efficacy in the reading classroom. The basal method involves a series of graded readers, workbook and supplementary materials. It is used for teaching reading in the first and second language situations. It is a structured teacher-centered method in which the teacher takes the upper hand in the interaction with the students. This method is grounded in Asubel's (1968) reception theory of learning which recognizes the teacher as the giver of knowledge. The teacher structures the learning materials which are presented in a hierarchical manner.

The language experience method is another method of teaching reading and it is based on Vygotsky's (1978) social constructivism theory which sees learning as a social activity. The teacher acts as the mediator in presenting learning experiences to the learners. It is a method in which students' interests and experiences are employed for teaching them to read.

The individualized method allows the students, on the other hand to progress at their own pace and rates as the students read from numerous books. Each student meets regularly with the teacher to identify his/her needs and to discuss what has been read. Brunner's (1966) cognitive constructivist theory which makes the learners to engage in inductive learning, obtaining knowledge by themselves provides the bedrock principles for the individualized method of teaching reading.

\section{Problem of the Study}

It has been observed that most secondary school teachers employ the basal method of teaching reading and many students do little or no reading. Many of them do not read beyond recommended texts. Although students are faced with a lot to read in order to succeed in school, most students are not effective readers by any standard hence majority perform poorly in public examinations. Could poor performance in English language be due to instructional method(s) employed by the teachers? Will a change in instructional method make a difference in achievement in reading comprehension? Which of the basal method, language experience method and individualized method will best enhance students' achievement in reading comprehension; and perhaps motivate them to read more?

\section{Purpose of the Study}

The objectives of this study are:

- To find out the relative effectiveness of three methods (the basal, the language experience and the individualized) method for teaching reading.

- To find out which of the basal, the language experience and the individualized methods of teaching reading that best enhances achievement in reading.

- To find out which of the methods motivates them to read more?

\section{Research Questions}

i. Is there a difference in reading comprehension achievement among students taught using different methods (basal, language experience and individualized) of teaching reading.

ii. Which of these three methods is most effective in teaching reading?

iii. Which of these methods motivate students to read more?

\section{Hypothesis}

There is no significant difference in reading comprehension achievement among students taught reading using different methods (basal, language experience and individualized) of teaching reading.

\section{Methodology}

This study was a quasi-experimental study which employed a non randomized pre-test-post-test control group design. Treatment packages in form of instructional packages were prepared and used as intervention. This design helped to test the effectiveness of the packages developed as treatment on participants' achievement in reading comprehension. The quasi-experimental design also helped to control for extraneous variables. Intact classes were used since it was not 
possible to randomize as in true experimental studies and this helped to eliminate the subject bias. It was also employed because in social sciences and humanities, it is difficult to use true experimental design.

The population of this study consisted of all Junior Secondary School Students (JSS 1 - JSS 3) in Benin Metropolis in Edo State, Nigeria with a total population of twelve thousand two hundred and three $(12,203)$ students.

The sample of study was made up of four hundred and ninety eight (498) students made up of two hundred and seventy three (273) boys and two hundred and twenty five (225) girls. To obtain this sample, two random sampling techniques were employed. First the schools were stratified according to school type (All-boys, All-girls and mixed schools). Then using simple random sampling technique, one school was selected from each school type. From each school, three intact classes were selected and assigned to treatment groups. Nine intact classes were used from the three schools selected. The schools selected were labeled I, II and III and the intact classes were labeled A, B and C. Classes $A$ and $B$ were the experimental groups taught using the experimental methods (the language experience method and the individualized method), while the classes $\mathrm{C}$ were the control group taught using the basal method (the traditional and conventional method of teaching reading and most commonly used for reading instruction in schools).

Reading corners were established in classes taught using the individualized method. The reading corners were stocked with journals, books (including story-books, novels), news papers and magazines.

Two achievement tests tagged 'Reading Comprehension Tests I and II (RCAT)' were used to collect data from the students. Each comprehension passage had ten multiple choice questions. Two different tests of equal difficulty level were used as pretest and post-test to eliminate students' familiarity with the tests.

To ensure the validity of the instrument; a table of specification was used to ensure that all levels of thinking were represented (knowledge, comprehension and application). Also, the instrument was pilot tested on fifty (50) respondents who were not part of the study sample. The scores obtained from the respondents in the pilot study were subjected to Kuder Richardson Formula 20 (KR-20) and internal consistency reliability coefficients of 0.71 and 0.85 were obtained from the two tests respectively.

The pre-test was administered by the researcher three days to the commencement of treatment and the post test was administered on the last day of treatment. Each group was exposed to a 35 minutes lesson per week for eight weeks.

Data collected was analyzed using Univariate Analysis of Coviariance (ANCOVA) and descriptive statistics. To establish the direction of significance, a post-hoc analysis was carried using Scheffe's Post Hoc Test. The hypotheses was tested at 0.05 level of significance.

Hypothesis: There is no significant difference in reading comprehension achievement among students taught using the different methods (the basal, the language experience and the individualized) of teaching reading.

Table 1: Mean Distribution for the Effects of Methods (Treatment)

\begin{tabular}{|l|c|c|c|}
\hline Methods & N & Mean & Standard Deviation \\
\hline Language Experience & 171 & 11.73 & 3.031 \\
\hline Individualized & 165 & 11.92 & 3.238 \\
\hline Basal & 162 & 8.57 & 3.422 \\
\hline Total & 498 & 10.77 & 3.567 \\
\hline
\end{tabular}

Table 1 shows that the mean score of students taught using the language of experience method was 11.73 as against 11.92 for those exposed to the individualized method and 8.57 for those taught using the basal method.

To determine the effects of instructional method from the mean differences shown above, Univariance Analysis of Covariance (ANCOVA) was used as presented in Table 2 using the post test scores as dependent variables.

Table 2: Summary of ANCOVA for the Effects of Method

\begin{tabular}{|l|c|c|c|c|c|}
\hline Source & Type III Sum of Squares & df & Mean Square & F & Sig. \\
\hline Corrected Model & 2592.311 & 3 & 864.104 & 114.360 & .000 \\
\hline Intercept & 3491.068 & 1 & 3491.068 & 462.025 & .000 \\
\hline Pre test score & 1434.543 & 1 & 1434.543 & 189.855 & .000 \\
\hline Method & 1651.624 & 2 & 825.812 & 109.292 & .000 \\
\hline Error & 3732.669 & 494 & 7.556 & & \\
\hline Total & 64058.000 & 498 & & & \\
\hline Corrected Total & 6324.980 & 497 & & & \\
\hline
\end{tabular}


Table 2 shows an F-value of 109.292 significant at .000 which is significant at 0.05 level. This shows that there is a significant difference in the effects of the methods. Therefore, the null hypothesis which stated that there is no significant difference in reading comprehension achievement among students taught using different methods of teaching reading was rejected. It was therefore concluded that there was a significant method effect on students' achievement in reading comprehension.

To determine which of the three methods was most effective in teaching reading, a post-hoc analysis was conducted using Scheffe's Post Hoc test. The result is summarized in Table 3.

Table 3: Scheffe's Post Hoc Test for the Direction of Significance Based on Methods on Students' Achievement in Reading Comprehension

\begin{tabular}{|c|c|c|c|c|c|c|}
\hline (I) Method & ]) Method & $\begin{array}{c}\text { Mean Difference } \\
(\mathrm{I}-\mathrm{J})\end{array}$ & $\begin{array}{c}\text { Std } \\
\text { Error }\end{array}$ & Sig. & \multicolumn{2}{|c|}{ 95\% Confidence Interval } \\
\hline Language Experience & Individualized method & -190 & .353 & .852 & -1.02 & .64 \\
\hline Method & Basal method & $3.157^{*}$ & .354 & .000 & 2.32 & 3.99 \\
\hline Individualized method & $\begin{array}{l}\text { Language experience method } \\
\text { Basal }\end{array}$ & $\begin{array}{c}-190 \\
3.347^{*}\end{array}$ & $\begin{array}{l}.353 \\
.357\end{array}$ & \begin{tabular}{|l|}
.852 \\
.000
\end{tabular} & $\begin{array}{l}.64 \\
2.51\end{array}$ & $\begin{array}{l}1.02 \\
4.19\end{array}$ \\
\hline Basal Method & $\begin{array}{l}\text { Language experience method } \\
\text { Individualized method }\end{array}$ & $\begin{aligned} & 3.157^{*} \\
&-3.347^{*}\end{aligned}$ & $\begin{array}{r}-/ 354 \\
.357\end{array}$ & .000 & $\begin{array}{l}-3.99 \\
-4.19 \\
\end{array}$ & $\begin{array}{l}-2.32 \\
-2.51 \\
\end{array}$ \\
\hline
\end{tabular}

* The mean difference is significant of the 0.05 level.

Table 3 reveals that the mean difference between the language experience method (LEM) was significant at .000 , showing that LEM is superior to BM. Also, the mean difference between the individualized method (IM) and the language experience method (LEM) is .190, significant at .852 and the mean difference between the individualized method and the basal method is 3.347 significant at .000 which is significant at 0.05 level of significance showing that the individualized experience method is significantly superior to the basal method. There is also a significant difference between the language experience method and the basal method and between the individualized method and the basal method. The individualized method is superior to the language experience method and the language experience method is superior to the basal method.

\section{Discussion}

The findings of this study revealed that the students taught reading using the individualized method performed better than the students taught using the language experience method as well as those taught using the basal methods. The students taught using the individualized method sought for the materials they read, and read at their own pace and time. The fact that the students selected their reading materials must have made them to see reading as a pleasurable activity and not a chore which they were forced to accomplish. The finding is in consonance with the findings of Greaney (1970), Obianika (1981), Gbenedio (1994) and Kasten and Wilfong (2005). All these researchers are of the view that the individualized method of teaching reading inculcated in their subjects positive attitude towards reading and reading for pleasure.

The effects of language experience method are also impressive. It came close to the individualized method in its effect on reading achievement. Both methods are child-centered, and this may be responsible for its appeal to the students. The study revealed that the language experience method is also an effective method of teaching reading. The students taught using the LEM had a mean score of 11.73 which came close to the performance of the students taught using the individualized method with a mean score of 11.92. The findings of this study are in agreement with the findings of Andzayi (1999) and Landis, Umolu and Mancha (2010).

Students taught reading using the basal method performed least in the reading achievement tests. Many factors could have accounted for this. The students taught using the basal method had no opportunity to select their reading materials. The all-knowing teachers chose their reading materials from their class reader which they followed rigidly and religiously. This method seems not to have stimulated the students' interest in reading nor sharpened their interest to find reading a pleasurable activity. It is possible that the students taught using the basal method would find reading a chore, a burden and boring. The findings of this study is in consonance with the findings of Greaney (1971), Obianika (1981) and Thames, Reeves, Kazeklskis et al (2008) who found that the basal method developed basic reading skills in the students but did not help in the development of recreational reading. 
The study has confirmed that method of reading instruction is a major variable in students' performance in reading comprehension. An appropriate method of instruction boosts learning outcome. The individualized method proved to be the best way for teaching reading because it did not only help the students to select their own reading materials, read them at their desired time and pace but also facilitated their reading skills and improved greatly their attitude towards reading.

\section{Recommendation}

English language teachers should be encourages using the individualized method since it is superior to both the language experience and the basal method. This means that teachers should be taught, through seminars and in-service training, how to use the individualized and the language experience methods in order to upgrade their knowledge in the various pedagogical methods for teaching reading. No teachers can use a method that he/she does not understand or know how to use.

Attention should be paid to the teaching of reading to the secondary school level as it is the practice in primary schools. Students should be given time in the school for silent reading. This would help to sharpen their interest in reading and improve their reading skills; Class teachers should strive to establish reading corners in their classes, to encourage students to read more extensively; School libraries should be stocked with books as this enables students to have quiet places to read; Libraries should be established by the three tiers of the government (federal, state and local government) in major cities and such libraries should be manned by qualified librarians who would assist the students in the selection of these reading materials; Reading specialists should be employed in schools to assist students in reading programmes; Teachers should be encouraged to read for leisure to enable them serve as reading models to their students. They should take cognizance of the reading materials that appeal to their students, and give incentives to students who select and read on their own. It is the duty of teachers to find out what students like to read and provide them so as to stimulate their interest in reading.

\section{References}

Andzayi, C. (1999). Mother tongue intervention programme using the language experience approach for Nigerian children with reading failure. Literacy and Reading in Nigeria, 8(1\&2), 149-155.

Arua, E.A. (2002). Enhancing the basal reading programme in Nigeria primary schools. Literacy and Reading in Nigeria, 9(1), 168-171.

Asubel, D. (1968). Educational Psychology: A Cognitive View. New York: Holt, Renehart \& Winston.

Brozo, W.G. \& Simpson, M.I. (2003). Taking seriously the ideas of reform: One high school's effort to make reading more responsible to all students. Journal of Adolescent and Adult Literacy, 47, 14-23.

Brunner, J.S. (1966). Towards a theory of instruction. Cambridge Massachusetts: Harvard University Press.

Gbenedio, U.B. (1994). Individualized reading instruction strategy and the development of positive attitude to reading. Nigerian Journals of Educational Research, 1(1), 93-109.

Greaney, V. (1970). A comparison of individualized and basal reader approach to reading instruction. The Irish Journal of Education, $4(11), 19-29$.

Kasten, W.C. \& Wilfong, L.G. (2005). Encouraging independent reading with ambience: The book bistro in middle and secondary classes. Journal of Adolescent and Adult Literacy, 48(4), 658-664.

Landis, D., Umolu, J. \& Mancha, S. (2010). The power of language experience for cross-cultural reading and writing. The Reading Teacher, 63(7), 580-589.

National Centre to Improve the Tools of Educators (1996). Learning to read - reading to learn. Helping children with disabilities to succeed. The First Chapters in Education. Eric Clearing House of Disabilities and Gifted Education. [Online] Available: http:///ericec/frstchap.html (July 20, 2015)

Obianika, U.B. (1981). The relative effectiveness of two methods of inculcating reading skills. Unpublished Ph.D. Thesis. University of Ibada, Nigeria.

Slavin, R.E., Karweit, N.L. \& Madden, N, N.A. (Eds). Effectiveness programmes for students at Risk. Boston: Allyn \& Bacon.

Thames, D.G., Reeves, C., Kazeskis, R. York, K., Boling, C., Newell, K. \& Wang, Y. (2008). Reading comprehension: Effects of individualized integrated language arts as a reading approach with struggling readers. Reading Psychology, 29, 86-115. 